Ivanova $\mathbf{N}$.

\title{
FORMATION OF THE INTEGRAL INDICATOR OF ECONOMIC SECURITY OF THE REGION BY TAXONOMY METHOD
}

Об’єктом дослідження є економічна безпека регіонів Украӥни. Одним з найбільш проблемних місць є відсутність загальноприйнятої методики оцінки економічної безпеки регіонів. Тому метою даного дослідження є спроба сформувати інтегральний показник економічної безпеки регіонів методом таксономії.

Для досягнення визначеної мети застосовувалися методи теоретичного узагальнення, аналізу та синтезу, логічного узагальнення, аналогій, порівняльного співставлення, метод таксономічного аналізу. Метод таксономічного аналізу дозволив побудувати узагальнюючу оцінку складного об'єкта або процесу, а саме показник економічної безпеки регіонів. Метод ретроспективного аналізу дозволив дослідити динаміку та визначити тенденцї змін інтегрального показника економічної безпеки регіонів України.

Розраховано інтегральний показник економічної безпеки регіонів методом таксономії за період 2008-2015 рр. За результатами проведених розрахунків зроблено висновок, що майже за весь період дослідження перше місще посідає Дніпропетровська область: 2008 - 0,67; 2009 - 0,58; 2010 - 0,7; 2011 - 0,72; 2012 та 2013 - 0,67; 2014 - 0,59 та 2015 - 0,65 пунктів. Виключенням є 2009 рік, коли найвище значення економічної безпеки зафіксовано у Донецької області (0,62). Весь період дослідження найнижче значення показника економічної безпеки зафіксовано у Чернівецької області, окрім 2015 року із найменшим значенням 0,05 у Луганської області. Розбіжність між максимальним та мінімальним значеннями інтегрального показника економічної безпеки коливається у середньому на рівні 0,55 пунктів: від 0,49 (2014) до 0,6 (2015). Це є досить значним відхиленням. При цьому за результатами проведених розрахунків можна стверджувати про тенденцію до зростання диспропориій щодо забезпечення економічної безпеки регіонів.

Прикладний характер запропонованої методики обгрунтовано його практичним застосуванням за фактичними даними соціально-економічного розвитку регіонів Украӥни за 2008-2015 рр. Недоліком запропонованої методики є відсутність математичної моделі розрахунку інтегрального показника економічної безпеки регіонів, але результати проведеного дослідження дозволяють в наступних дослідженнях розробити регресійні прогнозні моделі очінки регіональної економічної безпеки.

ключові слова: економічна безпека регіону, таксономічний аналіз, сочіально-економічний розвиток, інтегральний показник.

\section{Introduction}

The conditions for the decentralization of public administration strengthened the responsibility of the regions for the formation and maintenance of national economic security. Recently, more and more scientists are paying attention to the problems of ensuring the economic security of the regions, identifying threats to their economic security and forming an integral indicator of the state of economic security of the regions.

Given the number of regional economic security measures, it is advisable to use multivariate statistical methods to assess and forecast the economic security of regions. Therefore, it is urgent to study the economic security of regions through the formation of an appropriate integrated indicator of a certain taxonomy method.

\section{The object of research and its technological audit}

The object of research is the economic security of the regions of Ukraine.

In order to effectively formulate a strategy for managing regional development, in order to ensure regional and national economic security, an integral indicator of the economic se- curity of regions is studied. Ukrainian practice is not clearly approved at the legislative level and the generally accepted methodology for determining the indicator of economic security in the region. Foreign practice, like the Ukrainian one, is limited to determining the state of the level of national economic security, but changing the role of regions in public administration raises the need to define regional economic security as the basis for ensuring national economic security.

\section{The aim and objectives of research}

The aim of research is an attempt to form an integral indicator of economic security of regions (regions) of Ukraine by the taxonomy method.

To achieve this aim, it is necessary to perform the following tasks:

1. To form a sample of socio-economic development data for the regions of Ukraine for 2008-2015.

2. To carry out calculations of taxonomy coefficients according to the indicators of social and economic development of the regions of Ukraine for the period 2008-2015.

3 . To make a retrospective analysis of the integral indicator of economic security of the regions for 2008-2015.

4. To determine the disproportions of the state of economic security of the regions. 


\section{Research of existing solutions of the problem}

To date, there is no generally accepted at the state level methods for calculating regional economic security. In studies of economic security, most often pay attention to threats that may arise in relation to the subjects of the national economy, classifying them according to different criteria [1-5].

In particular, the authors of [1] on the basis of the classification model of threats to economic security in the region determine the impact of the most important factors of regional development on the degree of manifestation of individual threats. The authors [2] assess the state of economic security of the regions of Ukraine taking into account the effect of the threat of a decline in the production of industrial products. Investigation of the factors of occurrence of industrial hazards depending on the production specialization of the region is presented in [3]. The author [4] investigates factors of industrial production and problems of formation of industrial security of Ukrainian regions, and also determines the impact of production and technological threats on the level of economic security.

According to the author of the paper [5] In order to adequately assess the level of economic security, it is necessary to constantly monitor the influence of various factors, since their action is multi-polar and, depending on the situation, they can hinder or contribute to security.

From the point of view of the author [6], when investigating the economic security of the regions, it is necessary to consider the determinants that must be delineated relative to the meso- and macrolevel. In order to evaluate the determinants of meso- and macrolevels, in the author's opinion [6], it is advisable to use expert judgment, as well as PEST-analysis.

An alternative solution to the problem of assessing the economic security of the regions, set forth in [7-11], which involves a quantitative measurement of the actual development of regions (social, economic, industrial, demographic, etc.) using a mathematical apparatus.

A significant contribution to solving the problem of determining the economic security of the regions came from scientists [7] who integrated the existing methodology for calculating the level of economic security of Ukraine [8] to the regional level and presented in the form of methodological recommendations.

In work [9] the author develops a set of models for measuring the actual level of economic security of the territorial system and a multi-criteria optimization model for determining the state of a territorial system that is optimal from the point of view of economic security. A modified approach that envisages the use of the available statistical base, and the essence of which is to take into account the main components of the economic security subsystems - food, investment, foreign trade and social, are presented in [10].

The authors [11] present methods for an integrated assessment of the region's economic security, which includes the following components:

1) choice of indicators of economic security measurement at the level of administrative-territorial units of the region - districts and cities;

2) quantitative and qualitative spatio-temporal assessment of the components of the region's economic security by formalization methods;
3) quantitative and qualitative spatio-temporal integrated assessment of the region's economic security;

4) classification of the administrative-territorial unit of the region in accordance with the level of economic security;

$5)$ creation of a synthetic map of the geospatial organization of the ES region;

6) development of future scenarios for ensuring the economic security of the region by SWOT analysis.

Thus, the results of the analysis make it possible to conclude that it is expedient and necessary to use multidimensional statistical methods when investigating the economic security of regions through the multicriteria nature of their measurement. The quantitative approach to measuring the economic security of the region allows to investigate the dynamics of the integral indicator, determine its threshold values and develop a system for early warning of threats to the region's economic security [12].

\section{Methods of research}

To solve the problems, the following methods are used: analysis and synthesis, logical generalization, analogies, comparative comparison, method of taxonomic analysis.

To form an integral indicator of economic security in the region, let's suggest using the taxonomy method. The main purpose of using the taxonomy method is construction of a generalized estimate of a complex object or process. The taxonomic indicator is calculated according to the classical algorithm of taxonomic analysis, containing the following stages:

- formation of an observation matrix;

- standardization of the values of elements of the observation matrix;

- identification of the reference vector;

- determination of the distance between individual observations and the vector-standard;

- calculation of the taxonomic coefficient of development.

The procedure of standardization and data normalization is carried out with the purpose of bringing all the indicators to the same value (making them comparative). This procedure is carried out by the expression:

$$
y_{i j}=\frac{x_{i j}-\bar{x}_{j}}{\delta_{j}}
$$

where $x_{i j}$ - the $i$-th realization of the $j$-th attribute; $\bar{x}_{j}-$ arithmetic mean of the $j$-th attribute; $\delta_{j}$ - standard deviation of the $j$-th attribute.

Statistica or SPSS programs have built-in appropriate modules that allow to automate the standardization of data.

It should be noted that when determining the reference vector, it must be taken into account that for stimulants it has the maximum value of the standardized index; for disincentive factors - the minimum value.

The distance between individual observations and the vector-standard $\left(C_{i 0}\right)$ is calculated by the formula:

$$
C_{i 0}=\sqrt{\sum_{i=1}^{m}\left(Z_{i j}-Z_{0 j}\right)^{2}}
$$

where $Z_{i j}$ - the standardized value of each indicator; $Z_{0 j}-$ reference vector (for stimulators - the maximum value, for disincentive factors - the minimum value). 
The taxonomic coefficient of regional economic security $\left(Q_{i}\right)$ is calculated according to the scheme shown in Fig. 1.

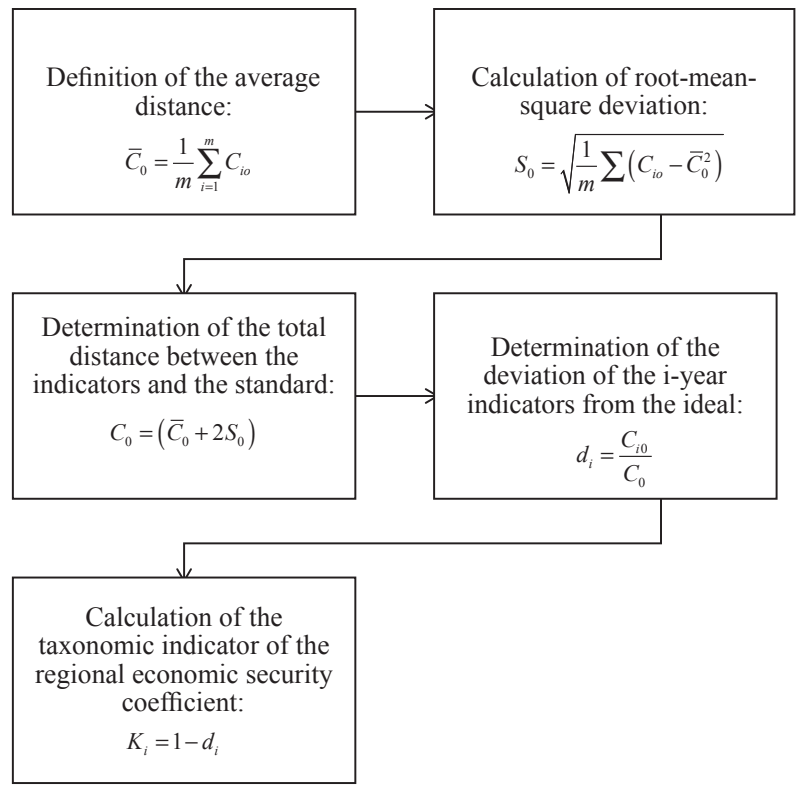

Fig. 1. Scheme for calculating the taxonomic coefficient of regional economic security $\left(K_{i}\right)$

So, the method of taxonomic analysis allows to construct a general estimation of a complex object or process. Application of the method of retrospective analysis allows to explore the dynamics and determine the trends of changes in the integral index of economic security of the regions of Ukraine.

\section{Research results}

The initial data for the calculations are the indicators of social and economic development of 24 regions of Ukraine (excluding Crimea and temporarily occupied territories) according to data from 2008-2015 [6], that is, the sampling of data was 192 observations for 17 indicators. The components of the integrated indicator of economic security of the regions identified 17 main indicators of socio-economic development of the regions according to the State Statistical Service of Ukraine:

- population size $(X 1)$;

- number of people engaged in economic activities $(X 2)$;

- disposable income of the population per person $(X 3)$;

- population expenditures per person $(X 4)$

- average monthly salary (X5);

- consumer price index $(X 6)$;

- gross regional product $(X 7)$;

- volume of sold industrial products, (goods, services) $(X 8)$

- agricultural products $(X 9)$;

- crop production $(X 10)$;

- livestock products (X11);

- commissioning of the total area of housing $(X 12)$;

- retail turnover of enterprises $(X 13)$;

- export of goods and services $(X 14)$;

- import of goods and services $(X 15)$;

- financial result (balance) of ordinary activities before taxation $(X 16)$;

- capital investments (X17).

Data sampling in 2015 are presented in Table 1.

Similar observation matrices are compiled for the periods $2008-2014$

Table 1

Initial data for calculation of the taxonomic indicator of economic security in Ukraine's regions, 2015

\begin{tabular}{|c|c|c|c|c|c|c|c|c|c|c|c|c|c|c|c|c|c|}
\hline Region & $X 1$ & $X 2$ & $X 3$ & $X 4$ & $X 5$ & $X Б$ & $X 7$ & $X 8$ & $X 9$ & $X 10$ & $X 1$ & $X 12$ & $X 13$ & $X 14$ & $X 15$ & $X 16$ & X17 \\
\hline Vinnytsia & 02.2 & 4.9 & 626.7 & 37231.7 & 3396 & 138.8 & 871 & 3.7 & 221.4 & 5.7 & .7 & $\exists 1$ & 11.43 & 91 & 28 & 2 & 7.40 \\
\hline Volyn & 2.7 & 7.3 & 473.5 & 5 & 3291 & 143.3 & 1688 & 8 & 6434.4 & 7.6 & 76.8 & 329 & 11.62 & 68 & 64 & -3.2 & 6.20 \\
\hline & 4.9 & 9.6 & & & 6 & 2.6 & & & & & & 40 & 72 & 9 & 63 & 46.6 & 5.90 \\
\hline Donet & 65.1 & 6.3 & 8816.8 & 20654.5 & 4980 & 146.9 & 15012 & 174390.4 & 6938.1 & 469.8 & 468.3 & 43 & 5.11 & 07 & .40 & \begin{tabular}{|l|}
-61.7 \\
\end{tabular} & 30 \\
\hline Zhyt & 47.5 & 506.6 & 27029.6 & 36297 & 3271 & 143.7 & 38425 & 5 & 8063.2 & 5252.3 & 2810.9 & 213 & 10.79 & 0.47 & 1.26 & 0 & .00 \\
\hline & 59.2 & 9.3 & 446.7 & 313 & 3381 & 144 & 952 & 138 & 9 & 3.3 & 3.6 & 442 & 12.24 & 28 & 1.03 & 1.6 & 80 \\
\hline Zapt & 53.6 & 45.1 & 35379 & 44348.2 & 4200 & 142.1 & 9061 & 1347 & 10055.7 & 932.1 & 123.6 & 101 & 22.16 & 3.07 & .15 & -2.7 & .80 \\
\hline Ivano- & 1382.3 & 558.3 & 25612.7 & 37607.8 & 3402 & 143.4 & 45854 & 34049.9 & 5697.3 & 2709.4 & 2987.9 & 856 & 10.57 & 0.42 & 0.31 & -7.2 & 9.60 \\
\hline Kyiv & 32.2 & 739.9 & 3072.2 & 47162.4 & 4153 & 144.3 & 04030 & 728 & .2 & 6 & 3.6 & 1864 & 31.74 & 92 & 72 & 8.5 & $1.4 \mathrm{~L}$ \\
\hline & 3.1 & 36.8 & 728.4 & 37014 & 282 & 141.3 & 447 & 8 & .4 & .8 & 3.6 & 117 & 56 & 43 & 13 & -4.2 & 4.10 \\
\hline Luhan & 2205.4 & 306.3 & 14988.3 & 12739.5 & 3427 & 138.8 & 23849 & 229 & 4035.7 & 158.1 & 77.6 & 22 & 3.10 & 0.27 & 0.42 & -51.5 & 2.10 \\
\hline Lviv & 34.2 & 1042 & 28795.7 & 37456.6 & 3646 & 145.2 & 94690 & 57421.7 & 9024.9 & 471.5 & 3553.4 & 1165 & 29.16 & 1.58 & 1.50 & -7.6 & 3.40 \\
\hline & 88.2 & 38.7 & 749.7 & 39777.8 & 3984 & 14 & 195 & 3 & 2 & 7.9 & 3.3 & 168 & 11.39 & 2.05 & 0.63 & -2.7 & .00 \\
\hline Odesa & 90.3 & 1016.2 & 31567.6 & 48491.7 & 3897 & 144.6 & 99761 & 53139.9 & 10642.1 & 8550 & 2092.1 & 632 & 36.78 & 2.62 & 1.10 & \begin{tabular}{|l|}
-15.8 \\
\end{tabular} & 10.00 \\
\hline Poltav & 38.9 & 583.6 & 31749.3 & 39148.2 & 3783 & 145 & 95867 & 1111 & 16660.7 & 12902.2 & 3758.5 & 266 & 13.49 & 1.54 & 0.97 & 4 & 8.30 \\
\hline Rivne & 31.8 & \begin{tabular}{|l|l|}
487.7 \\
\end{tabular} & 26042.2 & 34927.2 & 3573 & 144.9 & \begin{tabular}{|l|}
35252 \\
\end{tabular} & 268 & 6408.7 & 4148.5 & 2260.2 & 361 & 9.42 & 0.40 & \begin{tabular}{|l|}
0.22 \\
\end{tabular} & -5.3 & 4.30 \\
\hline Sumy & 13.3 & \begin{tabular}{|l|}
470.5 \\
\end{tabular} & 29772.9 & 35953.7 & 3449 & 145.5 & 41567 & 36745.3 & 9847.5 & 7779.5 & 2068 & 157 & 8.14 & 0.64 & 0.47 & 4.7 & 3.70 \\
\hline Terr & 65.7 & 406.2 & 23241.2 & 32479.9 & 2994 & 145.1 & 26656 & 12171.7 & 8145.8 & 5806.7 & 2339.1 & 480 & 7.35 & 0.33 & 0.27 & -2.1 & 3.80 \\
\hline Khe & 18.6 & 1230.8 & 31224.3 & 50662 & 3697 & 144.2 & 124843 & 112114.4 & 14679.5 & 11443.9 & 3235.6 & 384 & 36.81 & 1.57 & 1.39 & \begin{tabular}{|l|}
-2.7 \\
\end{tabular} & 11.20 \\
\hline & 1062.4 & \begin{tabular}{|l|l|}
445.8 \\
\end{tabular} & 26457.6 & 38488.4 & 3123 & 145.8 & 32215 & 17072.8 & 10836.1 & 8520.2 & 2315.9 & 113 & 10.99 & 0.26 & 0.15 & 2.4 & 3.10 \\
\hline Khmelr & 1294.4 & 500.5 & 28339.5 & 34321.9 & 3371 & 142.5 & 41088 & 26918.4 & 11598.7 & 8131.5 & 3467.2 & 469 & \begin{tabular}{|l|l|}
10.06 \\
\end{tabular} & 0.42 & 0.27 & -0.5 & 6.80 \\
\hline Ch & 1243 & 523.5 & 26700.3 & 37971 & 3360 & 143.8 & 50843 & 47744.1 & 14622.1 & 8855.7 & 5766.4 & 193 & 11.06 & 0.45 & 0.25 & 3.7 & .50 \\
\hline & 909.9 & 367.2 & 23490.5 & 32953.1 & 3050 & 142 & 18506 & 6817.6 & 4287.4 & 2638.5 & 1648.9 & 382 & 7.66 & 0.13 & 0.08 & U.4 & 2.80 \\
\hline Chernihiv & 1045 & \begin{tabular}{|l|}
432.3 \\
\end{tabular} & 27672.1 & 36705.7 & 3295 & 145.6 & 36966 & 27603.9 & 9924.9 & 7772.3 & 2152.6 & 190 & 8.86 & 0.57 & 0.39 & 3.5 & 3.50 \\
\hline
\end{tabular}

Note: compiled by the author according to [6]. 
The elements of the observation matrices have different units of measurement, the standardization procedure is performed to equalize the characteristic values, in this case the standardization is carried out with the help of the corresponding module of the Statistica program.

The results of data standardization are presented in Table 2.

According to Table 2, the reference vector is defined: for stimulators, the maximum value of the standardized indicator; for disincentive factors - the minimum value. To disincentive factors among certain indicators let's attribute only $X 6$ - consumer price index.

According to Table 2 it is possible to conclude that the most reference in terms of 2015 is indicators of the Dnipropetrovsk region.

At the next stage, the taxonomic coefficients of economic security in the region $\left(K_{i}\right)$ are calculated according to the presented scheme (Fig. 1)

The results of the calculations are given in Table 3 .

The results of the calculations indicate changes in the indicator of economic security of the regions (Fig. 2).

So, with respect to 2008 , in 2015 , significant changes have been made in such regions as Donetsk and Luhansk region:
- as of the end of 2015, the indicator of economic security of Donetsk region decreased by 0.38 points and reached the value of 0.28 ;

- Luhansk region according to 2015 has an index of economic security of 0.05 , which is 0.27 points less than the value of 2008 .

The data in Fig. 2 indicate that in 2015, compared to 2008, the level of economic security has been improved by such regions as:

- Kyiv (+0.14);

- Kharkiv $(+0.04)$;

- Odesa $(+0.02)$;

- Lviv (+0.07);

- Zaporizhzhia $(+0.02)$;

- Poltava $(+0.03)$;

- Vinnytsia $(+0.05)$;

- Mykolaiv (+0.03);

- Khmelnitskyi (+0.03);

- Ivano-Frankivsk (+0.04);

- Sumy $(+0.01)$;

- Zhytomyr $(+0.01)$;

- Kirovohrad (+0.02);

- Volyn $(+0.02)$;

- Chernihiv (+0.004);

- Rivne (+0.01).

Table 2

Matrix of standardized indicators $\left(Z_{i j}\right)$, 2015

\begin{tabular}{|c|c|c|c|c|c|c|c|c|c|c|c|c|c|c|c|c|c|}
\hline Region $\quad$ Indicators & $X 1$ & $X 2$ & $X 3$ & $X 4$ & $x 5$ & $X \sqsubseteq$ & $X 7$ & $X 8$ & $X 9$ & $X 10$ & $X 11$ & $X 12$ & $X 13$ & $X 14$ & $X 15$ & $X 16$ & $X 17$ \\
\hline Vinnytsia & 0.07 & 0.16 & 0.23 & \begin{tabular}{|l|}
0.02 \\
\end{tabular} & \begin{tabular}{|l|}
-0.43 \\
\end{tabular} & \begin{tabular}{|l|}
-2.41 \\
\end{tabular} & -0.09 & -0.17 & 2.06 & 1.44 & 69 & -0.03 & -0.40 & -0.30 & -0.63 & 0.76 & -0.05 \\
\hline Volyn & 0.74 & -0.79 & -0.62 & 0.08 & -0.66 & -0.16 & -0.71 & -0.61 & -0.88 & -1.10 & -0.13 & -0.18 & -0.39 & -0.45 & -0.21 & 0.30 & -0.25 \\
\hline Dniprc & 1.90 & 2.90 & 2.20 & \begin{tabular}{|l|}
1.27 \\
\end{tabular} & 1.64 & -0.51 & 3.32 & 3.61 & 1.29 & 1.20 & 1.06 & -0.16 & 2.74 & 3.50 & .26 & -2.07 & 2.98 \\
\hline Donetsk & 3.11 & 0.44 & -1.36 & -2.00 & 2.95 & 1.64 & \begin{tabular}{l|l}
1.12 \\
\end{tabular} & 1.71 & -0.76 & -0.83 & -0.35 & -0.89 & -0.09 & 1.78 & 0.68 & -2.90 & 0.10 \\
\hline Zhytam & -0.49 & -0.42 & -0.10 & -0.09 & -0.70 & \begin{tabular}{|l|}
0.04 \\
\end{tabular} & -0.56 & -0.52 & -0.48 & -0.58 & -0.10 & -0.47 & -0.46 & -0.59 & -0.65 & 0.48 & -0.61 \\
\hline Zakar & -0.48 & -0.37 & -1.23 & -0.69 & \begin{tabular}{|l|}
-0.47 \\
\end{tabular} & 0.19 & -0.77 & -0.69 & -1.47 & -1.61 & -0.68 & 0.10 & -0.33 & -0.06 & 0.25 & 0.39 & -0.64 \\
\hline Zapor & 0.11 & 0.40 & 1.60 & \begin{tabular}{|l|}
0.89 \\
\end{tabular} & 1.29 & -0.76 & 0.55 & 1.12 & 0.02 & 0.30 & -0.59 & -0.74 & 0.52 & 1.12 & 0.39 & 0.33 & 0.01 \\
\hline Ivano- & -0.33 & -0.24 & -0.39 & 0.07 & -0.42 & -0.11 & -0.40 & -0.39 & -1.07 & -1.41 & 0.02 & 1.12 & -0.48 & -0.62 & -0.59 & 0.08 & 0.31 \\
\hline Kyiv & 0.09 & 0.38 & 1.13 & 1.24 & 1.19 & 0.34 & \begin{tabular}{l|l}
0.88 \\
\end{tabular} & 0.19 & 1.04 & 0.55 & 1.75 & 3.60 & 1.35 & 0.36 & 2.21 & -0.53 & 2.73 \\
\hline Kirovohr & -0.82 & -0.82 & -0.16 & 0.00 & -0.68 & -1.16 & -0.56 & -0.56 & 0.26 & 0.67 & -0.72 & -0.71 & -0.65 & -0.61 & -0.80 & 0.25 & -0.59 \\
\hline Luhansk & 0.65 & -1.10 & -2.54 & -2.97 & -0.37 & -2.41 & -0.88 & -0.56 & -1.48 & -1.26 & -1.47 & -0.94 & -1.12 & -0.72 & -0.47 & -2.34 & -0.92 \\
\hline Lviv & 1.04 & 1.41 & 0.26 & 0.05 & 0.10 & 0.79 & 0.67 & -0.04 & -0.24 & -0.51 & 0.42 & 1.88 & 1.13 & 0.14 & 0.79 & 0.06 & 0.93 \\
\hline Mykolaiv & -0.60 & -0.41 & 0.25 & 0.33 & 0.82 & -0.06 & -0.35 & -0.38 & -0.26 & 0.08 & -0.89 & -0.58 & -0.41 & 0.45 & -0.22 & 0.33 & -0.28 \\
\hline Odesa & 0.87 & 1.32 & 0.82 & 1.40 & 0.64 & 0.49 & 0.78 & $-0,10$ & 0.17 & 0.50 & -0.61 & 0.56 & 1.79 & 0.83 & 0.33 & -0.39 & 0.37 \\
\hline Poltava & -0.26 & -0.15 & 0.86 & 0.26 & 0.39 & 0.69 & 0.70 & 0.77 & 1.67 & 1.92 & 0.56 & -0.34 & -0.22 & 0.11 & 0.17 & 0.70 & 0.10 \\
\hline Rivne & -0.60 & -0.48 & -0.30 & -0.26 & -0.06 & 0.64 & -0.63 & -0.50 & -0.89 & -0.94 & -0.49 & -0.10 & -0.58 & -0.64 & -0.70 & 0.19 & -0.56 \\
\hline Sumy & -0.65 & -0.54 & 0.46 & -0.13 & -0.32 & 0.94 & -0.49 & -0.35 & -0.03 & 0.25 & -0.63 & -0.61 & -0.69 & -0.48 & -0.40 & 0.74 & -0.66 \\
\hline Ternopil & -0.71 & -0.76 & -0.87 & -0.56 & -1.29 & 0.74 & -0.82 & -0.72 & -0.46 & -0.40 & -0.44 & 0.19 & -0.76 & -0.68 & -0.64 & 0.36 & -0.64 \\
\hline Kharkiv & 1.26 & 2.05 & 0.75 & 1.67 & 0.21 & 0.29 & 1.34 & 0.78 & 1.17 & 1.45 & 0.19 & -0.05 & 1.79 & 0.14 & 0.66 & 3.33 & 0.57 \\
\hline Khersan & -0.71 & -0.62 & -0.21 & 0.18 & -1.02 & 1.09 & -0.70 & -0.64 & 0.21 & 0.49 & -0.45 & -0.72 & -0.44 & -0.73 & -0.78 & 0.61 & -0.75 \\
\hline Khmelnytskyi & -0.44 & -0.44 & 0.17 & -0.33 & -0.49 & -0.56 & -0.50 & -0.50 & 0.40 & 0.36 & 0.36 & 0.16 & -0.52 & -0.62 & -0.64 & 0.45 & -0.15 \\
\hline Cherkasy & -0.50 & -0.36 & -0.16 & 0.11 & -0.51 & 0.09 & -0.29 & -0.18 & 1.16 & 0.60 & 1.98 & -0.52 & -0.44 & -0.60 & -0.66 & 0.68 & -0.52 \\
\hline Chernivtsi & -0.90 & -0.89 & -0.82 & -0.50 & -1.17 & -0.81 & -1.00 & -0.80 & -1.42 & -1.43 & -0.92 & -0.05 & -0.73 & -0.81 & -0.86 & 0.50 & -0.80 \\
\hline Chernihiv & -0.74 & -0.67 & 0.03 & -0.04 & -0.65 & 0.99 & -0.59 & -0.49 . & -0.01 & 0.25 & -0.57 & -0.53 & -0.63 & -0.53 & -0.49 & 0.67 & -0.69 \\
\hline $\begin{array}{l}\text { The reference }\left(Z_{0 j}\right) \\
\text { (5timulator - max, dis- } \\
\text { incentive factors - min) }\end{array}$ & 3.11 & 2.90 & 2.20 & 1.67 & 2.95 & 2.41 & 3.32 & 3.61 & 2.06 & 1.92 & 2.69 & 3.60 & 2.74 & 3.50 & 3.26 & 0.76 & 2.98 \\
\hline
\end{tabular}

Note: compiled by the author according to [6]. 
The results of calculation of the taxonomic indicator

\begin{tabular}{|c|c|c|c|c|c|c|c|c|}
\hline Regions & 2008 & 2009 & 2010 & 2011 & 2012 & 2013 & 2014 & 2015 \\
\hline Luhansk & 0.32 & 0.28 & 0.29 & 0.32 & 0.28 & 0.26 & 0.16 & 0.05 \\
\hline Chernivtsi & 0.14 & 0.12 & 0.13 & 0.13 & 0.12 & 0.11 & 0.10 & 0.12 \\
\hline Ternopil & 0.15 & 0.13 & 0.15 & 0.17 & 0.16 & 0.16 & 0.14 & 0.15 \\
\hline Kherson & 0.18 & 0.17 & 0.19 & 0.20 & 0.17 & 0.17 & 0.18 & 0.17 \\
\hline Zakarpattia & 0.18 & 0.16 & 0.17 & 0.17 & 0.15 & 0.16 & 0.14 & 0.17 \\
\hline Rivne & 0.17 & 0.16 & 0.19 & 0.19 & 0.17 & 0.18 & 0.15 & 0.18 \\
\hline Chernihiv & 0.18 & 0.17 & 0.18 & 0.20 & 0.20 & 0.20 & 0.17 & 0.18 \\
\hline Volyn & 0.17 & 0.16 & 0.17 & 0.18 & 0.17 & 0.17 & 0.16 & 0.19 \\
\hline Kirovohrad & 0.18 & 0.18 & 0.19 & 0.21 & 0.19 & 0.19 & 0.19 & 0.19 \\
\hline Zhytomyг & 0.19 & 0.19 & 0.20 & 0.21 & 0.20 & 0.20 & 0.19 & 0.20 \\
\hline Sumy & 0.19 & 0.20 & 0.19 & 0.22 & 0.21 & 0.21 & 0.20 & 0.20 \\
\hline Ivano-Frankivsk & 0.19 & 0.21 & 0.22 & 0.22 & 0.21 & 0.21 & 0.22 & 0.23 \\
\hline Khmelnytskyi & 0.22 & 0.22 & 0.23 & 0.24 & 0.24 & 0.24 & 0.25 & 0.25 \\
\hline Cherkasy & 0.26 & 0.27 & 0.27 & 0.27 & 0.26 & 0.25 & 0.25 & 0.25 \\
\hline Mykolaiv & 0.23 & 0.24 & 0.25 & 0.26 & 0.23 & 0.24 & 0.23 & 0.26 \\
\hline Donetsk & 0.66 & 0.62 & 0.64 & 0.70 & 0.58 & 0.59 & 0.52 & 0.28 \\
\hline Vinnytsia & 0.28 & 0.27 & 0.26 & 0.29 & 0.28 & 0.30 & 0.31 & 0.33 \\
\hline Poltava & 0.32 & 0.34 & 0.36 & 0.38 & 0.37 & 0.37 & 0.37 & 0.35 \\
\hline Zaporizhzhia & 0.37 & 0.36 & 0.37 & 0.37 & 0.36 & 0.37 & 0.36 & 0.40 \\
\hline Lviv & 0.34 & 0.36 & 0.38 & 0.40 & 0.40 & 0.39 & 0.37 & 0.41 \\
\hline Odesa & 0.40 & 0.43 & 0.42 & 0.40 & 0.42 & 0.42 & 0.38 & 0.41 \\
\hline Kharkiv & 0.42 & 0.47 & 0.42 & 0.46 & 0.48 & 0.48 & 0.47 & 0.46 \\
\hline Kyiv & 0.38 & 0.49 & 0.46 & 0.49 & 0.53 & 0.54 & 0.53 & 0.52 \\
\hline Dnipropetrovsk & 0.67 & 0.58 & 0.70 & 0.72 & 0.67 & 0.67 & 0.59 & 0.65 \\
\hline Maximum & 0.67 & 0.62 & 0.70 & 0.72 & 0.67 & 0.67 & 0.59 & 0.65 \\
\hline Minimum & 0.14 & 0.12 & 0.13 & 0.13 & 0.12 & 0.11 & 0.10 & 0.05 \\
\hline Discrepancy & 0.53 & 0.50 & 0.56 & 0.59 & 0.55 & 0.55 & 0.49 & 0.60 \\
\hline
\end{tabular}

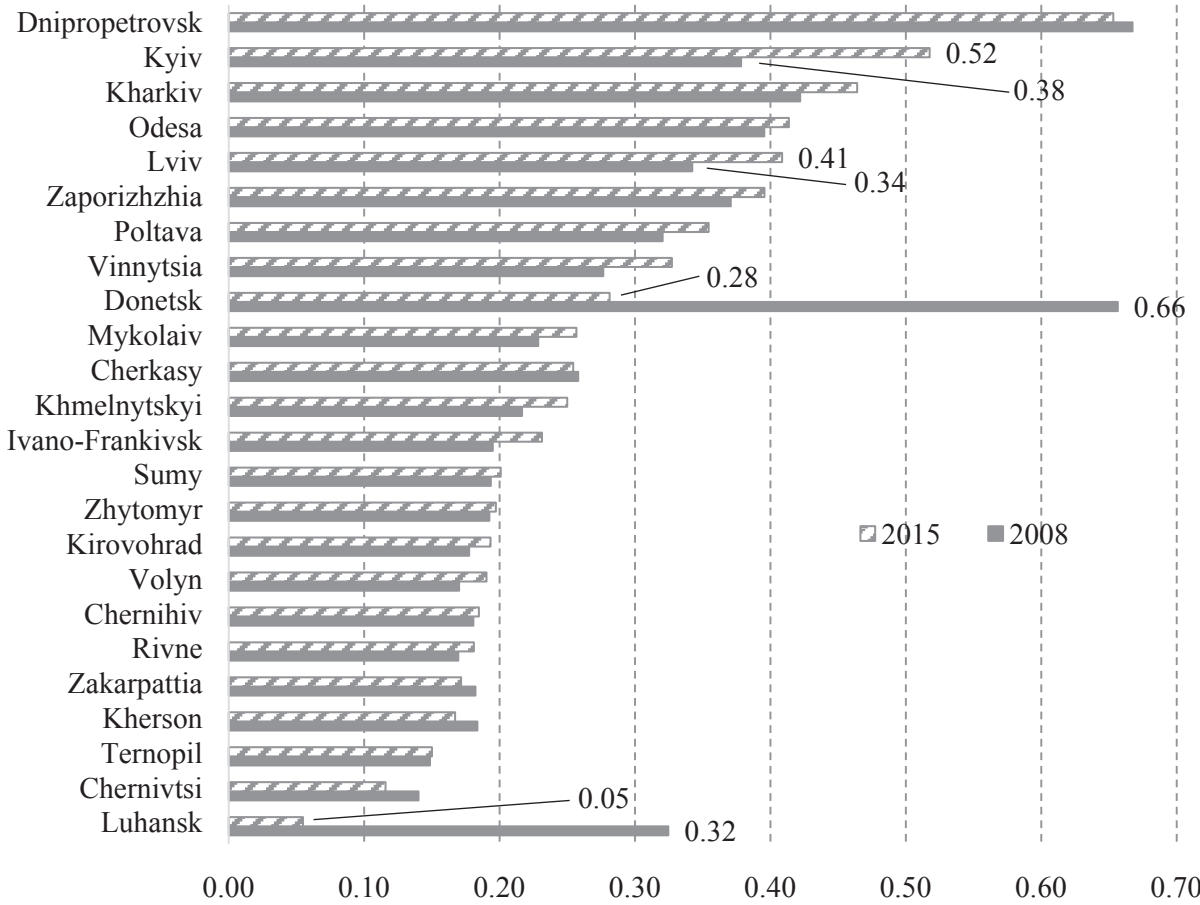

Fig. 2. Integral indicator of economic security of the regions of Ukraine in 2008 and 2015 
Based on the results of the calculations, it is concluded that Dnipropetrovsk region occupies the first place for almost the whole period of research: $2008-0.67 ; 2009-$ $0.58 ; 2010-0.7 ; 2011$ - $0.72 ; 2012$ and $2013-0.67$; $2014-0.59$ and 2015 - 0.65 (Fig. 3). An exception is 2009 , when a high value of economic security was recorded in the Donetsk region (0.62).

Almost the entire period of the study, the low value of the indicator of economic security was recorded in the Chernivtsi region, except for 2015 with the lowest value of 0.05 in the Luhansk region.

The data in Fig. 3 allows to determine the disproportions of the provision of economic security of the regions, that is, to calculate the disagreements between the maximum and minimum values of the indicator of economic security of the regions.

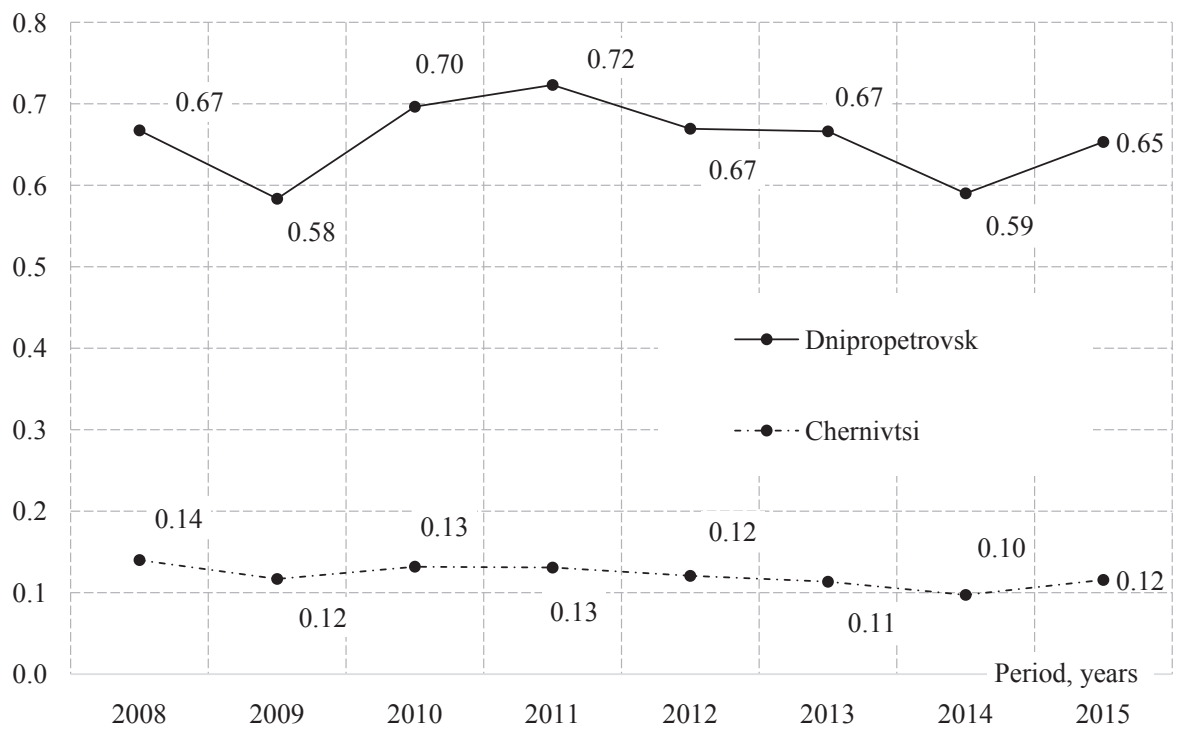

Fig. 3. Dynamics of the economic security index of Dnepropetrovsk and Chernivtsi regions

\section{Conclusions}

1. A sample of socio-economic indicators of the development of the regions of Ukraine for 2008-2015 is formed. (In addition to the temporarily occupied territories); the procedure for standardizing the data allows to determine the vector standards. According to observations, among the regions, standards are determined on specific grounds. Thus, the Kharkov region of six periods is the reference vector for the indicator «Population Expenditures per Person». Vinnytsia region in terms of «Agricultural products» and «Plant production». Dnipropetrovsk region - «Retail turnover of enterprises», «Import of goods and services» and «Financial result (balance) from ordinary activities before taxation», after 2013 - almost all other indicators. The Kyiv region for the whole period of research is the reference for the indicator «Acceptance of the total area of housing». Cherkasy region - by the indicator «Livestock products» until 2014. Donetsk region by 2013, almost all other indicators.

2. The calculation of the taxonomy coefficients for the indicators of social and economic development of the regions of Ukraine for the period 2008-2015 is carried out. During the entire period of the study, the high value of the integral index of economic security is observed in the Dnepropetrovsk region, which average value for 2008 2015 is 0.66 . The next value in the Donetsk region is at the level of 0.57 points, that is, the gap is 0.09 points. On 0.08 points the value of the Donetsk region in the Kyiv region is less.

The discrepancy between the maximum and minimum values of the integral index of economic security fluctuates on the average at the level of 0.55 points from 0.49 (2014) to 0.6 (2015). This is a rather significant deviation. At the same time, based on the results of the calculations, it is possible to assert that there is a tendency to increase disproportions in ensuring economic security of the regions.

\section{SWOT analysis of research results}

Strengths. The strength of research is the quantitative measurement of the integral indicator of economic security of each region of Ukraine (except temporarily occupied territories) and its retrospective analysis for 2008-2015.

Weaknesses. The weakness is that the proposed methodology does not have a specific calculation formula, which makes it impossible to calculate the economic security for each region separately (without calculating others).

Opportunities. Opportunities for further research are the development of a prognostic model of regional economic security based on the research results.

Threats. Threats to the results of the conducted research are that only integral indicators of social and economic development are used to calculate the integral indicator.
The least value of the integral index of economic security is recorded in the Chernovtsy region -0.12 points.

3. A retrospective analysis of the integral index of economic security of the regions for 2008-2015 is conducted. According to the results of calculations, there is a different trend in its changes across all regions. The tendency to increase is observed in such regions as Ternopil, Chernihiv, Khmelnytskyi, Ivano-Frankivsk, Kirovohrad, Volyn, Vinnytsia, Lviv, Kharkiv and Kiev regions. Rivne, Dnipropetrovsk and Odesa regions have an equal trend. All other regions tend to decrease the value of the integral indicator of regional economic security. The greatest value for almost all regions was recorded in 2011. But according to the results of the calculations in regions such as Volyn, Ivano-Frankivsk, Khmelnytskyi, Vinnytsia, Zaporizhzhia and Lviv regions, the high value of the integrated indicator of economic security is observed in 2015 .

4. The disproportions of the state of economic security of the regions are determined. Almost the entire period of research, the high value of the integral indicator of economic security of the regions based on the results of the calculations is recorded in the Dnipropetrovsk region. Almost the whole period of research, the low value of the indicator of economic security is recorded in 
the Chernivtsi region, except for 2015 with the lowest value of 0.05 in the Luhansk region. The discrepancy between the maximum and minimum values of the integral index of economic security fluctuates on the average at the level of 0.55 points from 0.49 (2014) to 0.6 (2015). That is a rather significant deviation, while according to the results of the calculations it is possible to affirm the tendency to increase disproportions in ensuring economic security of the regions.

\section{References}

1. Modeliuvannia ekonomichnoi bezpeky: derzhava, rehion, pidpryiemstvo: monograph / Heiets V. M. et al.; ed. by Heiets V. M. Kharkiv: INZhEK, 2006. 240 p.

2. Sukhorukov A. I., Moshenskyi S. Z., Petruk O. M. Natsionalna ekonomichna bezpeka: handbook / ed. by Sukhorukov A. I. Zhytomyr: Ruta, 2010. 384 p.

3. Holovchenko O. M. Ekonomichna bezpeka rehionu v harantuvanni stabilnosti natsionalnoi ekonomiky: monograph. Odessa: Bukaiev V. V., 2008. 399 p.

4. Babets I. H. Vyrobnycho-tekhnolohichni zahrozy ekonomichnii bezpetsi rehionu $\mathrm{v}$ umovakh interrehionalnoho spivrobitnytstva // Naukovyi visnyk Lvivskoho derzhavnoho universytetu vnutrishnikh sprav. Seriia ekonomichna. 2012. Vol. 2. P. 199-209. URL: http://nbuv.gov.ua/UJRN/Nvldu_e_2012_2_24

5. Bilyk R. V. Instytutsionalne zabezpechennia ekonomichnoi bezpeky rehioniv Ukrainy // Ekonomika i rehion. 2015. No. 4. P. 96-102. URL: http://nbuv.gov.ua/UJRN/econrig_2015_4_19

6. Tulchinskiy R. V. Strategic management principles of economic security in the regions // Economic bulletin of NTUU «KPI». 2017. No. 14. doi:10.20535/2307-5651.14.2017.108741
7. Sukhorukov A. I., Kharazishvili Yu. M. Efektyvnist sotsialnoekonomichnoho rozvytku ta ekonomichna bezpeka rehionu (na prykladi Zakarpatskoi oblasti). Kyiv: NISD, 2013. 32 p.

8. Pro zatverdzhennia metodyky rozrakhunku rivnia ekonomichnoi bezpeky Ukrainy: Order of the Ministry of Economy of Ukraine No. 60 from 02.03.2007. URL: http://consultant. parus.ua/?doc $=03 \mathrm{WN} 62 \mathrm{~B} 99 \mathrm{~B}$

9. Pilko A. D. Modeliuvannia protsesiv upravlinnia ekonomichnoiu bezpekoiu rehionu: Abstract's PhD thesis. Kyiv: KNEU, 2004. 21 p.

10. Pilko A. D., Savchuk N. V. Modeling the Process of Evaluation of the Level of Economic Security of Region // Biznes Inform. 2015. No. 8. P. 77-84. URL: http://nbuv.gov.ua/UJRN/ binf $2015 \quad 8 \quad 14$

11. Knysh M., Smaliychuk A. Integral assessment of economic security of a borderland region (the case of Lviv Oblast) // Journal of Geography, Politics and Society. 2017. Vol. 7, No. 2. P. 98-107. doi:10.4467/24512249jg.17.020.6636

12. Ivanova N. Ensuring of the economic safety of the region through the early warning and response threats // International Scientific Journal «Internauka». Series: «Economical Sciences». 2017. Vol. 1, No. 8. P. 50-54. doi:10.25313/25202294-2017-8-3206

13. State Statistics Service of Ukraine. URL: http://www.ukrstat gov.ua/ (Last accessed: 25.10.2017)

Ivanova Natalia, PhD, Associate Professor, Department of Marketing, Management and Public Administration, Donetsk National University of Economics and Trade named after Mykhailo TuganBaranozsky, Kryvyi Rih, Dnipropetrovsk region, Ukraine, e-mail: ivanova@donnuet.edu.ua, ORCID: https://orcid.org/0000-00025010-2668 